\title{
DCAF1 Gene
}

National Cancer Institute

\section{Source}

National Cancer Institute. DCAF1 Gene. NCI Thesaurus. Code C107420.

This gene plays a role in both the ubiquitination and phosphorylation of proteins. 